Institute of $\mathbf{F}_{\text {ood and }} \mathbf{A}$ gricultural $\mathbf{S}_{\text {ciences }}$

\title{
Conservation Tillage Peanut Production ${ }^{1}$
}

\author{
D. L. Wright, J. J. Marois, J. R. Rich, R. K. Sprenkel, and E. B. Whitty ${ }^{2}$
}

Peanuts are a very important part of the row crop economy in Florida. While peanuts are a high management, high input crop and the costs of inputs have steadily increased, peanut farmers are competing in a global market that keeps prices low. Yields have been stagnant for a number of years, even with new varieties and technology. To remain competitive, farmers must find ways to improve production efficiency or increase yields. Therefore, major trends in U. S. agriculture over the past 10 years have included a move to genetically modified crops, reduced tillage, and a bigger proportion of farm revenue coming from government programs. Peanut production has traditionally been a tillage intensive operation, but conservation tillage (or strip tillage, as it is known by producers in the southeast) has become a widely-accepted practice for most row crops and is gaining acceptance among peanut farmers.

The mid-to-late 70s saw the first commercial production of strip-till soybeans and corn. No-till without subsoiling had not been successful because the soil compaction layer was not broken and therefore root growth was limited to the top 6-8 inches of soil. This restricted root system resulted in crop failure in many years when rainfall was inadequate or irrigation was not available. There was also little planting equipment available to make strip tillage work, less equipment to control weeds, and fewer weed control options. Many of the equipment limitations have been worked out over the last 20 years. Most conservation tillage planting units used in the coastal plain now include an in-row subsoil shank that breaks the soil compaction layer while leaving the row middle undisturbed. Beginning in 1995, transgenic or Roundup Ready soybeans and cotton came on the market, which allowed Roundup to be applied over the top of crops for weed control. This led to widespread adoption of no-till and strip tillage of these crops, since weed control was no longer the major concern of strip till farmers. Many of the new cotton growers or those expanding their acreage started farming all of their cotton using strip tillage. Yet peanut farmers have been slow to move to conservation tillage, partially due to the belief that plant residue left on the soil surface causes increased disease on peanut. Growers felt they had little incentive to change a program that had not only worked successfully for many years but often supported other parts of the farming operation. However, many studies over the past 20 years have shown that disease pressure is the same or sometimes

1. This document is SS-AGR-185, one of a series of the Agronomy Department, Florida Cooperative Extension Service, Institute of Food and Agricultural Sciences, University of Florida. First published October 2002. Visit the EDIS Web Site at http://edis.ifas.ufl.edu.

2. D. L. Wright, professor, J. J. Marois, professor, J. R. Rich, professor, R. K. Sprenkel, associate professor, North Florida Research and Education Center, and E. B. Whittey, professor, Agronomy Department, Cooperative Extension Service, Institute of Food and Agricultural Sciences, University of Florida, Gainesville, Florida, 32611.

The use of trade names in this publication is solely for the purpose of providing specific information. UF/IFAS does not guarantee or warranty the products named, and references to them in this publication does not signify our approval to the exclusion of other products of suitable composition.

The Institute of Food and Agricultural Sciences is an equal opportunity/affirmative action employer authorized to provide research, educational information and other services only to individuals and institutions that function without regard to race, color, sex, age, handicap, or national origin. For information on obtaining other extension publications, contact your county Cooperative Extension Service office. Florida Cooperative Extension Service/Institute of Food and Agricultural Sciences/University of Florida/Christine Taylor Waddill, Dean. 
less when planting into a cover crop, as compared to the plow/plant method of peanut production. This has also been the case with tomato spotted wilt, which has become the most limiting disease to peanut production in the southeast. This information, along with years of success planting corn, cotton, and soybean using conservation tillage techniques, has led to the spread of strip tillage production of peanuts.

\section{Getting Started}

Implementing new farming practices creates new challenges and risks. Preparing fields a year in advance, land selection, crop rotation, type of cover crop, pest management, soil fertility, and type of equipment are all decisions that are necessary to ensure a successful crop. County agents and the Natural Resource Conservation Service personnel can help provide a management plan for successful conversion to strip-till production of peanut and can provide references to those who are already involved in strip-till production.

In spite of preplanning and talks with experienced strip till farmers, weather is the biggest uncontrolled factor that puts the crop at risk. Irrigation can take some of the uncertainty out of the equation, but poor weather at harvest can still cause major crop losses. Although it cannot overcome all of the stresses that weather might bring, strip tillage can help in reducing erosion and conserve moisture. Advantages associated with strip-tilling peanuts, besides moisture preservation, less sandblasting and erosion, are a reduction in labor, fuel, and equipment repairs, more time for management, and less tomato spotted wilt virus disease. The total benefit to using strip tillage for a 1,000-acre farm in Florida has been calculated to be $\$ 18,000$ if yields are the same for both systems. Some of our research with cotton has shown as much as a \$75/A advantage with yield increases using genetic technology where over-the-top herbicides can be used. Many farmers who have been in strip-till crop production for several years will tell you they would quit farming before going back to plowing and using conventional tillage practices.
There are many steps to follow to ensure successful production of strip-till peanuts. These are no different from any other crop using strip-till planting. Growing peanuts by any method should have a well-planned approach to production and marketing. After all of the equipment is in place, planning for strip tillage normally starts the previous year with selection of fertilizers, fields, and cover crops.

\section{Fertilization}

Direct fertilization of peanuts and soybeans is not as critical as for some crops and is no different for strip-tilled than for conventional-till peanuts. However, special attention should be paid to calcium, boron, and $\mathrm{pH}$ in either tillage system. Research in Georgia has shown that lime should not be plowed under before planting peanuts or it will have little or no effect on calcium uptake by pods, although $\mathrm{pH}$ adjustment will occur. With strip tillage, lime should be applied well in advance of planting if the subsoil is very acid, or should be incorporated prior to planting cover crops in the fall. Peanuts grow best at a $\mathrm{pH}$ of 5.8 to 6.2. Availability of soil nutrients and nitrogen fixation are optimized in this range. Zinc toxicities can occur when the $\mathrm{pH}$ is below 5.5. Manganese deficiency may occur when the $\mathrm{pH}$ is above 6.2. The liming program should be based on a soil test and use dolomitic or calcitic limestone to obtain the target $\mathrm{pH}$ range. Peanuts have a high calcium requirement and samples for soil tests should be from the top 2-3 inches instead of 6 inches to ensure that adequate calcium is available in the pegging zone of strip-till peanuts. There should be at least $250 \mathrm{ppm}$ of calcium and a 3:1 Ca:K ratio or higher for runner peanuts. All Virginia-type or large-seeded peanuts or those grown for seed should receive additional calcium regardless of soil test levels. Apply $400 \mathrm{lbs} / \mathrm{A}$ of gypsum at early bloom to meet this additional calcium need. Gypsum contains about $20 \%$ calcium and about $16 \%$ sulfur. Boron is critical to flowering, pod development and nut quality. Usually a half pound of boron is adequate to meet the needs of a peanut crop. This may be applied with preplant fertilizer or with an early fungicide application. Boron should be applied prior to early bloom, since it influences pollination. 
Peanuts are very good at using residual nutrients from the previous crop or cover crop. Seldom do peanuts respond to direct fertilization of phosphorus or potassium. Therefore, if peanuts are in rotation with crops that are fertilized adequately, no phosphorus or potassium will be needed.

\section{Variety Selection}

Many new runner-type peanut varieties are being introduced that have resistance to tomato spotted wilt, leaf spot, cylindrocladium black rot (CBR) and other unique oil and maturity characteristics. In variety trials across the southeast, no differences have been noted in variety response to tillage. Highest yielding varieties in one type of tillage are highest yielding in another. Therefore, varieties should be chosen on the basis of yield, grade, and pest resistance, and then on the basis of the maturity that best fits the farming operation. Varieties range in maturity from about 125 days to almost 150 days. Variety trials are conducted each year at multiple locations with results being published in EDIS fact sheet SS-AGR-44 "Peanut Varieties" (http://edis.ifas.ufl.edu/AA199). Careful attention should be made to those varieties that perform best in multiple years and locations.

\section{Rotations and Cover Crops}

Good rotations increase crop yields, reduce pests, and recycle nutrients. Grass crops benefit from nitrogen produced by a previous legume crop, and peanuts usually do best after grass crops-especially after bahiagrass. Rotations also help growers plan labor needs for planting and harvesting. Not only do crops have different planting and maturity dates, but different water requirements and can decrease the risk of a total crop loss if a severe drought occurs at a critical growth period for one crop but not for another. Much is known about rotating peanuts with grass crops. Crops like perennial grasses, corn, grain sorghum, millet, cotton, and small grains have been shown to have benefits to peanuts when they are planted preceding them. Some of the benefits are use of residual fertility, less disease, and better weed control due to use of different herbicides. If peanuts follow peanuts, leaf spot starts earlier and takes more sprays than when peanuts follow one of the grass crops. Peanut root knot nematode and soilborne diseases such as stem rot (white mold) can become serious if peanut follow peanuts. Initially, yields may not always be a great deal lower, but the expense of growing the crop will be much higher due to the need for extra pest management.

Many growers begin to strip till by planting into previous crop residue. The reason for this is that growers are not accustomed to planting cover crops and it is not commonly known how much value a good cover crop can contribute to the primary crop. However, it may be good to begin without a cover crop, since residue can create problems if not managed properly or if equipment has not been set up right. Strip tillage can be successful without a cover crop, but many of the benefits of a good mulch residue are not obtained. Some of the benefits of a good cover crop versus previous crop residue include:

- less soil erosion,

- increased moisture retention during periods of high rainfall,

- increased organic matter when managed for high residue production,

- reduction in sand blasting on the emerging crop, and

- higher levels of water infiltration.

A good cover crop has to be planned in much the same manner as the main crop. Small grain cover crops or perennial grasses are better at building organic matter than are legume cover crops. Legume cover crops have very little fiber in the plant tissue and decompose rapidly. They will release most of the $\mathrm{N}$ from the plant tissue in the first 30 days after being killed. Most legumes mature later in the spring than small grains and therefore have to be killed before much dry matter is produced. Small grains (wheat, oats, rye) can be planted over a wide period of time on more infertile soils than many of the legumes. Small grain should be killed 3-4 weeks ahead of planting to keep from depleting soil moisture, to reduce cutworm, southern corn root worm and other soil pests, to eliminate tough stalks that have to be planted into, and to reduce any potential phytotoxic 
effects from the cover crop. Small grain cover crops planted in November can be top-dressed with about $30 \mathrm{lbs}$ N/A of liquid nitrogen and 2,4-D in late January or early February. The 2,4-D application will get rid of many of the winter broadleaf weeds and make the small grain cover crop and remaining weeds easier to kill in late March when the small grain is headed out, and the nitrogen will stimulate growth of the small grain for better cover. Our data have shown that soil temperatures can be 25 degrees cooler on the soil surface with straw mulch as compared to bare soil between peanut rows on plowed fields. Peanut seed germination may be slower with early planting in conservation tillage than in conventional tillage because of lower soil temperatures. However, pegging may be better because of cooler soils. Canopy temperatures have been measures to be about 5 degrees cooler in strip till as compared to conventional tilled peanuts $\left(96^{\circ} \mathrm{F}\right.$ vs. $\left.101^{\circ} \mathrm{F}\right)$. Likewise, available soil moisture was $30 \%$ higher during periods of hot, dry weather. Bahia or bermudagrass provide the best rotation crop for peanut because it results in a significant yield increase due to reducing nematodes, increasing organic matter and soil tilth, and grass roots penetrating the compaction layer, leaving channels for the peanut roots to follow into the subsoil. Systems research is now showing that bahiagrass can economically be used in crop rotations with profits being double that of a continuous row crop system. The model can be found at http://nfrec.ifas.ufl.edu/marois/index.html.

\section{Planting and Management}

Farmers who begin strip tilling for the first time should talk to growers who have had experience with strip tillage, so they can plan prior to the season preferably the year before, when management of the cover crop can be taken into account. Since tillage operations are eliminated, the planting operation should be timely, but you need to be aware of problems that may occur controlling the cover crop or killing winter weeds or with some other practice. There is normally a shift in the types of weeds that are encountered since winter weeds have a chance to emerge. Some of the winter weeds can be very difficult to control if not controlled before planting. Glyphosate alone will not control several broadleaf weeds and therefore other herbicides need to be used in combination or in sequence. After successfully killing the cover crop, it takes about 3-4 weeks for the weeds or cover crop to become brittle so that planting can be done with ease.

Proper adjustment of the strip till equipment is essential to adequately preparing a seedbed and planting in the same pass. One of the main problems encountered by new growers is "blowout", where big patches of the cover crop will come up, leaving a rough seedbed for the planter. The main cause is that the cutting coulter ahead of the subsoil foot is not cutting deep enough and the subsoil foot pulls the plants out by the root, leaving an uneven planting surface for the planter. This can usually be overcome by tightening up on the top link of the tractor or letting the lift lower, causing the coulters of the strip till rig to cut deeper into the cover crop. Generally, if the toolbar of the strip till rig is level, this will not be a problem. Another cause of "blowout" is that the cover crop is not killed far enough ahead of planting and stems are still tough and the coulter of the strip till rig cannot cut through the residue, causing dragging and poor seedbeds. This can be solved by going to another field that was killed earlier or making sure that you have 3-4 weeks between killing the cover crop and planting. It is normally easier to plant through completely green cover crops or those that have been killed 3-4 weeks; however, green cover crops can harbor insects and may have dried out the soil for the crop being planted. After a few years, the coulter on the strip-till rig will wear until it becomes too small to adequately cut through the cover crop and poor seedbeds may result in spite of all of the adjustments that are made. At this time, replace the cutting coulter with the largest one that can be mounted on the strip till rig.

Data from Florida, Georgia, and Alabama have shown a yield advantage of about 400-500 lbs/A, as well as a reduction in tomato spotted wilt, with twin row peanuts as compared to single-row planting. Other advantages with twin rows include the lapping of row middles as much as two weeks earlier, which helps in weed control, and higher grades, since peanut tends to put on more of a taproot crop and less of a limb crop. These factors result in more value for the grower. But can strip-till peanut be planted in twin 
rows? Yes, but it is a little more difficult, since both rows need to be planted over a single subsoil slot. Most strip till rigs will tear up a strip through the cover crop about 8-10 inches wide. This is enough to allow twin rows to be planted on either side of the slot. Also, with twin rows, the two sets of twin rows being plowed up with the same plow should be 36 inches to the outside of the twin rows. This may mean moving in the subsoil feet on those rows by 7 to 9 inches to ensure that the rows are planted on either side of the subsoil slot. However, in heavy residue, there is often straw that may interfere with planter operation and seed are often left on the surface when planting through a thick mat of straw. Most planters can be equipped with row cleaners which will physically remove straw in front of the double disk of the planters. Even with these, plant populations are often slightly less in twin-row strip-tilled peanuts as compared to twin-row conventional-tilled planted peanuts, though yields are often similar. Six seed per foot of row is recommended in single rows and three seed in each of the double rows for the same seeding rate on an acre basis. A stand of 4 plants per foot of row is critical for those areas where tomato spotted wilt is a problem.

\section{In-Season Management and Pest Control}

Weed management is the first problem encountered with strip-till peanuts. A good kill of the cover crop and weeds present at planting is essential to successful peanut production. If peanuts are given a competitive advantage early on, they will spread and lap sooner, making weed control less expensive and resulting in higher yields. Generally, weed control options in strip-till peanuts are the same as for those in conventional till systems. Refer to EDIS fact sheet SS-AGR-03 "Weeds in the Sunshine:

Weed Management in Peanuts"

(http://edis.ifas.ufl.edu/WG008) for a complete list of materials and weeds controlled. Cover crops are killed by herbicides prior to planting strip-till, and herbicides replace plowing in conventional tillage at a fraction of the cost. Some weeds like Florida pusley can be easily controlled with preemergence residual herbicides. However, if it escapes due to poor herbicide activation, little can be done chemically for control during the season. Cultivation of peanut should be avoided during the growing season if weeds can be controlled by chemicals. If peanuts are planted into a high-residue cover crop, residue will decay during the growing season, leaving a mellow surface for peanuts to peg into and allow good water infiltration. If there are weed escapes that cannot be chemically controlled, high-residue cultivators do a very good job of cutting weed roots while maintaining surface residue. Plowing depth of high-residue cultivators is slightly deeper than in conventional cultivation. Therefore, care must be taken to not prune peanut roots. With the wide array of herbicides on the market, farmers rarely plow peanuts after planting, and conventional-tilled peanuts normally have the same weed control program as strip-tilled peanuts after planting.

Insect control in strip tillage differs little from conventional tillage, except in a few instances. If peanuts are planted within a couple of weeks of killing the cover crop, cutworms can be more of a problem. However, if the cover crop is killed 3-4 weeks ahead of planting, cutworms offer no more problem than with tillage. Lesser cornstalk borers prefer loose, dry, sandy soils, and are therefore less of a problem in strip till crops than with conventional tillage. Extended hot, dry conditions can lead to outbreaks of lesser corn stalk borer in all types of plantings, but damage will be less for strip-tilled peanuts than those planted into tilled fields. Thrip numbers have been shown to be fewer in reduced-tillage fields and therefore show a reduction in tomato spotted wilt. Reduced tillage is a factor in the Tomato Spotted Wilt Virus Index developed by the University of Georgia. Reduced tillage is thought to increase the number and diversity of beneficial insects. However, insect problems will not be the major consideration for growers in deciding whether to use strip tillage on peanuts.

Disease and nematode control is usually no different for strip-tilled or conventionally-tilled peanuts. As previously mentioned, strip till peanuts consistently have less TSWV than do conventionally-till peanuts, and recent research in both Georgia and Florida show that severity of leaf spot is also reduced with strip tillage. Control measures can be found in EDIS fact sheets ENY-002 "Peanut Nematode Management" (http://edis.ifas.ufl.edu/NG016) and PDMG-V1-10 
"Disease Management in Peanuts"

(http://edis.ifas.ufl.edu/PG031). Rotation has much more influence on the number and frequency of fungicide applications than does tillage. There are several new peanut varieties that have more leaf spot resistance that may allow growers to reduce the number of fungicide applications in half or more, while making as good or better yields if proper rotations are used.

\section{Harvesting}

No difference in harvesting is noted between strip-tilled and conventionally tilled peanuts. Frequently asked questions by new strip-till peanut farmers are: 1) will the residue from the previous crop interfere with digging and 2) will there be more foreign material in the harvested peanuts? The answer to both is no. When peanuts are strip-tilled into cotton residue, stalks tend to decay slowly due to their high fiber content. However, with a cover crop on top of cotton stalks, no impediments to digging or harvesting have been noted. Peanuts have been strip-till planted into bahiagrass that was killed in the fall, as well as in corn, sorghum, cotton, and soybean residue, without any problem during digging and harvest. Actively growing weeds in the crop at digging and weather conditions cause more problems for both strip till and conventional planted peanuts than seedbed conditions at planting.

\section{Summary}

The decision to strip-till plant peanuts can bring many benefits to the farming operation. These benefits include advantages to the soil, reduction in environmental impact, savings in fuel, labor, and equipment repairs, and ultimately more profit. Regardless of the method of planting, it is important to plan and evaluate each production step and to perform the operation in a precise and timely manner. Conservation compliance standards to further reduce environmental impact and to qualify for farm payments may make it more important to look at reduced tillage as a part of the farming operation. 